\title{
Correction to: Population Pharmacokinetics of Abrocitinib in Healthy Individuals and Patients with Psoriasis or Atopic Dermatitis
}

\author{
Jessica Wojciechowski ${ }^{1}$ (D) Bimal K. Malhotra ${ }^{2} \cdot$ Xiaoxing Wang $^{1} \cdot$ Luke Fostvedt $^{3} \cdot$ Hernan Valdez $^{2}$. \\ Timothy Nicholas ${ }^{1}$
}

Published online: 18 February 2022

(c) The Author(s) 2022

\section{Correction to: Clinical Pharmacokinetics https://doi.org/10.1007/s40262-021-01104-z}

The article "Population Pharmacokinetics of Abrocitinib in Healthy Individuals and Patients with Psoriasis or Atopic Dermatitis", written by Jessica Wojciechowski, Bimal K. Malhotra, Xiaoxing Wang, Luke Fostved, Hernan Valdez and Timothy Nicholas was originally published electronically on the publisher's internet portal on 21st January 2022 without open access.

With the author(s)' decision to opt for Open Choice the copyright of the article changed on 28th January 2022 to $($ ) The Author(s) 2022 and the article is forthwith distributed under a Creative Commons Attribution-Noncommercial 4.0 International License, which permits any non-commercial use, sharing, adaptation, distribution and reproduction in any

The original article can be found online at https://doi.org/10.1007/ s40262-021-01104-z.

Jessica Wojciechowski

Jessica.Wojciechowski@pfizer.com

Bimal K. Malhotra

Bimal.K.Malhotra@pfizer.com

Xiaoxing Wang

Xiaoxing.Wang@pfizer.com

Luke Fostvedt

Luke.Fostvedt@pfizer.com

Hernan Valdez

Hernan.Valdez@pfizer.com

Timothy Nicholas

Timothy.Nicholas@pfizer.com

1 Department of Global Product Development, Pfizer Inc., Groton, CT, USA

2 Department of Global Product Development, Pfizer Inc., New York, NY, USA

3 Department of Global Product Development, Pfizer Inc., Cambridge, MA, USA medium or format, as long as you give appropriate credit to the original author(s) and the source, provide a link to the Creative Commons license, and indicate if changes were made. The images or other third-party material in this article are included in the article's Creative Commons license, unless indicated otherwise in a credit line to the material. If material is not included in the article's Creative Commons license and your intended use is not permitted by statutory regulation or exceeds the permitted use, you will need to obtain permission directly from the copyright holder. To view a copy of this license, visit http://creativecommons. org/licenses/by-nc/4.0/.

The original article has been corrected.

Open Access This article is licensed under a Creative Commons Attribution-NonCommercial 4.0 International License, which permits any non-commercial use, sharing, adaptation, distribution and reproduction in any medium or format, as long as you give appropriate credit to the original author(s) and the source, provide a link to the Creative Commons licence, and indicate if changes were made. The images or other third party material in this article are included in the article's Creative Commons licence, unless indicated otherwise in a credit line to the material. If material is not included in the article's Creative Commons licence and your intended use is not permitted by statutory regulation or exceeds the permitted use, you will need to obtain permission directly from the copyright holder. To view a copy of this licence, visit http://creativecommons.org/licenses/by-nc/4.0/. 